\title{
Implementasi Pendidikan Demokrasi Dalam Pembelajaran IPS STUDY KASUS SMA Negeri 6 Takalar.
}

\author{
Syahban Nur ${ }^{1}$ Sudarsono ${ }^{2}$ \\ ${ }^{1}$ Pendidikan Sosiologi, Universitas Muhammadiyah Makassar \\ Email:syahbannur@unismuh.ac.id \\ ${ }^{2}$ Pendidikan Sosiologi, Universitas Muhammadiyah Makassar \\ Email: sudarsono@unismuh.ac.id
}

\begin{abstract}
The objectives of this study are (1) To learn how to apply democratic education to social studies subjects at Takalar Public High School 6 (2) To find out whether the inhibiting factors are in the implementation of democratic education in the social studies learning process at Takalar 6 Public High School and (3) To Learning the supporting factors in learning democracy in the process of social studies learning at Takalar Public High School 6.

This type of research is qualitative with naturalistic research. This research was conducted at Takalar Public High School 6. The data sources used are primary data sources in the form of interviews and secondary data sources in the form of documents. The population in the study was all students of class X IPS 1 Takalar Public High School 6. The research sample is class X IPS1. Data collection techniques used are interview, observation, and documentation techniques.

The results of this study indicate that (1) Implementation of Democracy Education in Social Sciences Subjects at SMA 6 Takalar has been well implemented with the values of democracy that are instilled as partnerships, cooperation, freedom, consideration, freedom, group protection, others, self-confidence and awareness of the differences made through the method of discussion, lecture, question and answer, and assignment, (2) Supporting Factors in the Implementation of Democracy Education in Social Studies Learning Processes in Takalar Public High School 6, Supporting Facilities and Infrastructure that can be used by teachers between LCDs Other, Laptops, and some supporting reference books are supporting factors for the success of the learning process, and (3) Inhibiting Factors in Implementing Democracy Education in Social Studies Learning Processes at Takalar Public High School, namely individual differences, the choice of abilities between students becomes unavoidable, because every student has the ability different.
\end{abstract}

Keywords : Democracy Education, Social Studies Subjects

Abstrak. Tujuan penelitian ini adalah (1) Untuk mengetahui bagaimana implementasi pendidikan demokrasi pada mata pelajaran IPS di SMA Negeri 6 Takalar (2) Untuk mengetahui apakah faktor-faktor penghambat pada implementasi pendidikan demokrasi dalam proses pembelajaran IPS di SMA Negeri 6 Takalar dan (3) Untuk mengetahui faktor-faktor pendukung pada implementasi pendidikan demokrasi dalam proses pembelajaran IPS di SMA Negeri 6 Takalar.

Jenis penelitian ini adalah kualitatif dengan pendekatan naturalistik. Penelitian ini dilakukan di SMA Negeri 6 Takalar.Sumber data yang digunakan yaitu sumber data primer berupa hasil wawancara dan sumber data sekunder berupa dokumen-dokumen.Populasi dalam penelitian adalah seluruh siswa kelas X IPS 1 SMA 
Negeri 6 Takalar. Sampel penelitian ini yaitu kelas X IPS1. Teknik pengumpulan data yang digunakan yaitu teknik wawancara, observasi, dan dokumentasi.

Hasil penelitian ini menunjukan bahwa (1) Implementasi Pendidikan Demokrasi Pada Mata Pelajaran IPS di SMA Negeri 6 Takalar sudah terimplementasikan dengan baik dengan nilai-nilai demokrasi yang ditanamkan yaitu toleransi, kerjasama, kebebasan berpendapat, kebebasan berpartisipasi, kebebasan berkelompok, menghormati orang lain, kepercayaan diri dan kesadaran akan perbedaan yang dilaksanakan melalui metode diskusi, ceramah, tanya jawab, Dan penugasan, (2) Faktor-Faktor Pendukung Pada Implementasi Pendidikan Demokrasi Dalam Proses Pembelajaran IPS di SMA Negeri 6 Takalar yaitu Sarana dan Prasarana pendukung yang dimanfaatkan guru antara lain LCD, Laptop, dan beberapa buku referensi pendukung menjadi faktor penunjang keberhasilan proses pembelajaran, dan (3) Faktor-Faktor Penghambat Pada Implementasi Pendidikan Demokrasi Dalam Proses Pembelajaran IPS di SMA Negeri 6 Takalar yaitu Perbedaan individual, perbedaan kemampuan antar siswa menjadi sesuatu yang tidak terhindarkan, karena setiap siswa memiliki kemampuan yang berbeda.

Kata kunci : Pendidikan Demokrasi, Mata Pelajaran IPS

\section{PENDAHULUAN}

Indonesia diketahui sebagai salah satu negara yang menganut sistem demokrasi, menyadari betapa pentingnya pendidikan demokrasi sejak dini secara terencana, sistematis dan berkesinambungan dalam pembangunan dan pembentukan masyarakat, berbangsa dan bernegara di Indonesia.Pendidikan demokrasi juga ikut andil membentuk karakter bangsa agar bersikap jujur, adil dan transparan.

Kata demokrasi berasal dari bahasa Yunani yaitu Demos dan Kratein.Demos berarti rakyat sedangkan kratein berarti kekuasaan. Bentuk kekuasaan dari, oleh, dan untuk rakyat. Secara instrumental, pendidikan demokrasi di indonesia sudah di gariskan dalam berbagai peraturan perundangan. Seperti dalam usulan BP KNIP tanggal 29 Desember 1945 dikemukakan bahwa "Pendidikan dan pengajaran harus membimbing siswa-siswi menjadi warga negara yang mempunyai rasa tanggung jawab".

Pendidikan demokrasi pada hakikatnya adalah sosialisasi nilai-nilai demokrasi agar dapat diterima dan dijalankan oleh warga negara.Pendidikan demokrasi adalah upaya sistematis yang dilakukan oleh negara dan masyarakat untuk memfasilitasi individu warga negara agar memahami, menghayati, mengamalkan, dan mengembangkan konsep, prinsip, dan niali demokrasi sesuai dengan status dan perannya di msayarakat (Udin S. Winataputra, 2012).

Pendidikan demokrasi bertujuan mempersiapkan warga masyarakat untuk berperilaku dan bertindak demokratis, melalui aktifitas yang menanamkan pada generasi muda akan pengetahuan, kesadaran, dan nilai-nilai demokrasi. Zamroni (2011) mengatakan bahwa pendidikan demokrasi harus mampu melahirkan manusia-manusia yang demokratis tanpa manusia yang memegang teguh nilainilai demokrasi, masyarakat yang demokratis hanya akan merupakan impian belaka.

Pancasila sebagai landasan ideologi negara terafiliasi dengan pelaksanaan kehidupan demokrasi sehari-hari.Hal ini sesuai dengan pendapat Darmodiharjo dalam Sunarso dkk (2008: 80), bahwa demokrasi Pancasila adalah paham demokrasi yang bersumber kepada kepribadian dan falsafah hidup bangsa Indonesia.

Indonesia sebagai negara demokrasi mengupayakan perwujudan nilai-nilai demokrasi dalam kultur pemerintahan dan kehidupan masyarakat. Carter dan Herz dalam Miriam Budiarjo (1980: 8687), menyatakan bahwa kultur kehidupan demokratis terlihat dari adanya pemerintahan yang mampu menjamin hak-hak individu secara konstitusional, adanya badan kehakiman yang bebas dan 
tidak memihak, pemilihan umum yang bebas, kebebasan untuk menyatakan pendapat, serta kebebasan untuk berserikat.

Indonesia sebagai negara yang demokratis memiliki beberapa permasalahan terkait pelanggaran nilai-nilai demokrasi.Beberapa pelanggaran yang terjadi diantaranya pada pelaksanaan Pemilu.Beberapa permasalahan yang terjadi seperti politik uang, kebocoran hak suara, kampanye hitam, penggelapan jumlah DPT (Daftar Pemilih Tetap), hingga panitia penyelenggara Pemilu yang kurang profesional.

Dunia pendidikan juga memiliki permasalahan terkait dengan pelanggaran nila-nilai demokrasi. Beberapa permasalahan diantaranya fenomena guru otoriter, diskriminasi sosial, perkelahian antar pelajar, dan bullying di antara para siswa. Beberapa guru masih mempraktikan cara mengajar yang otoriter. Paul Suparno menyatakan bahwa masih banyak guru tidak dapat menerima gagasan siswa yang berlainan dengan yang mereka ajarkan, siswa banyak dikekang kebebasan berpikirnya dan bahkan dimatikan kreativitasnya (Tonny D. Widiastono, 2004: 128).

Interaksi yang berjalan di antara guru dan siswa di sekolah juga masih kurang demokratis.Hal ini terbukti dengan adanya diskriminasi dan kasus bullying.Kebanyakan kasus diskriminasi dilatarbelakangi oleh adanya stratifikasi sosial ekonomi di masyarakat (Pupuh Faturahman dkk, 2013: 23).Komisi Perlindungan Anak Indonesia (KPAI) menyatakan bahwa kasus bullying juga masih tetap terjadi di sekolah.

Pendidikan memegang peran penting dalam mengembangkan nilai-nilai dan cita-cita demokrasi bagi generasi muda kita.Sekolah dalam hal ini sebagai penyelenggara pendidikan harus mampu menyelenggarakan pendidikan demokrasi.Sikap dan mental demokrasi harus ditanamkan dan dibiasakan melalui bahasa dan kajian serta kekuatan keteladanan (Amas Mahmud, 2011: 12).

\section{LANDASAN TEORI}

\section{Teori Demokrasi}

\section{Demokrasi Sebagai Suatu Nilai}

Demokrasi sebagai suatu nilai tidak hanya berkaitan dengan urusan kenegaraan saja, tetapi juga bisa dipraktekkan dalam kehidupan sehari-hari baik dalam keluarga maupun dalam masyarakat.

Nilai-nilai demokrasi sesungguhnya merupakan nilai-nilai yang diperlukan untuk mengembangkan pemerintahan demokratis. Berdasarkan nilai atau kondisi inilah, sebuah pemerintahan demokratis dapat ditegakkan. Sebaliknya, tanpa adanya kondisi ini, pemerintahan tersebut akan sulit ditegakkan.

Adapun nilai-nilai demokrasi antara lain sebagai berikut :

a. Kebebasan Berpendapat

Kebebasan berpendapat adalah hak bagi warga negara biasa yang wajib dijamin dengan undang-undang dalam sebuah sistem politik demokratis (Dahl, 1971).Kebebasan ini diperlukan karena kebutuhan untuk menyatakan pendapat senantiasa muncul dari setiap warga negara dalam era pemerintahan terbuka saat ini.Dalam masa transisi menuju demokrasi saat ini, perubahanperubahan politik, sosial, ekonomi, budaya, agama, dan teknologi seringkali menimbulkan persoalan bagi warga negara maupun masyarakat pada umumnya.

Hak untuk menyampaikan pendapat ini wajib dijamin oleh pemerintah sesuai dengan undang-undang yang berlaku sebagai bentuk kewajiban negara untuk melindungi warga negaranya yang merasa dirugikan oleh tindakan pemerintah atau unsur swasta. Semakin cepat dan efektif cara 
pemerintahan memberikan tanggapan, semakin tinggi pula kualitas demokrasi pemerintahan tersebut.

b. Kebebasan Berkelompok

Berkelompok dalam suatu organisasi merupakan nilai dasar demokrasi yang diperlukan bagi setiap warga. Kebebasan berkelompok ini yang diperlukan untuk membentuk organisasi mahasiswa, partai politik, organisasi massa, perusahaan, dan kelompok-kelompok lain. Kebutuhan berkelompok merupakan naluri dasar manusia yang tak mungkin diingkari.Dalam era modern ini, kebutuhan berkelompok ini tumbuh semakin kuat.Persoalan yang muncul ditengah masyarakat yang sedemikian kompleks seringkali memerlukan organisasi untuk menemukan jalan keluar.

c. Kebebasan Berpastisipasi

Kebebasan berpastisipasi ini sesungguhnya merupakan gabungan dari kebebasan berpendapat dan berkelompok. Jenis yang pertama adalah pemberian suara dalam pemilihan umum, baik pemilihan anggota DPR maupun pemilihan presiden bentuk partisipasi kedua yang belum berkembang luas di negara demokrasi baru adalah apa yang disebut sebagai kontak/hubungan dengan pejabat pemerintah.

d. Kerjasama

Kerjasama untuk mengatasi persoalan yang muncul dalam tubuh masyarakat. Akan tetapi, kerjasama hanya mungkin terjadi jika setiap orang atau kelompok bersedia untuk mengorbankan sebagian dari apa yang diperoleh dari kerjasama tersebut. Kerjasama bukan berarti menutup munculnya perbedaan pendapat antar individu atau antar kelompok. Kerjasama diperlukan bagi kelompok-kelompok untuk menopang upaya persaingan dengan kelompok lain.

Demokrasi tidak hanya memerlukan hubungan kerjasama antar individu dan antar kelompok.Kompetisi, kompromi, dan kerjasama merupan nilai-nilai yang mampu mendorong terwujudnya demokrasi.

\section{e. Kesetaraan Antar-Warga}

Kesetaraan atau egalitarisme merupakan salah salah satu nilai fundamental yang diperlukan bagi pengembangan demokrasi di Indonesia. Kesetaraan disini diartikan sebagai adanya kesempatan yang sama bagi setiap warga negara. Kesetaraan memberikan tempat bagi setiap warga negara tanpa membedakan etnis, bahasa, daerah, maupun agama.Nilai ini diperlukan bagi masyarakat heterogen seperti Indonesia yang sangat multi etnis.Nilai-nilai kesetaraan perlu dikembangkan dan dilembagakan dalam semua sektor pemerintahan dan masyarakat.Diperlukan usaha keras agar tidak terjadi diskriminasi atas kelompok etnis, bahasa, daerah atau agama.

f. Kedaulatan Rakyat

Dalam negara demokraasi, rakyat memiliki kedaulatan. Hal ini berarti bahwa rakyat berdaulat dalam menentukan pemerintahan.Warga negara sebagai bagian dari rakyat memiliki kedaulatan dalam pemilihan.

Dalam Orde Baru, para politisi boleh dikatakan tidak accountabilitas. Mereka berbuat sesuka hati dalam bentuk menikmati semua fasilitas dan kekuasaan yang dimilikinya untukkepentingan pribadi dan kelompok.

Akuntabilitas tergolong ke dalam kelompok nilai-nilai demokrasi yang sulit dikembangkan.Dalam era ORBA, praktis para politisi bisa dikatakan tidak accauntable.Mereka berbuat sesuka hati dalam bentuk menikmati semua fasilitas dan kekuasaan yang dimilikinya untuk kepentingan pribadi dan kelompok. 
Kondisi rezim ini sangat bertolak belakang dengan kondisi rezim demokrasi.Dalam demokrasi, justru harus accountabilitas, yakni melayani segala kebutuhan rakyat.

g. Rasa Pecaya (Trust)

Rasa percaya antar kelompok masyarakat merupakan nilai dasar lain diperlukan agar demokrasi dapat terbentuk. Sebuah pemerintahan demokrasi akan sulit berkembang bila rasa saling percaya satu sama lain tidak tumbuh.

Rasa percaya antar Kelompok masyarakat merupakan minyak pelumas untuk melancarkan relasi-relasi sosial politik yang ada dalam masyarakat yang sering terhalang oleh rasa ketakutan, kecurigaan, dan permusuhan yang berpotensi memendekkan proses demokrasi.

\section{h.Kesetaraan gender}

Kesetaraan gender adalah sebuah keniscayaan demokrasi, di mana kedudukan laki-laki dan perempuan memiliki hak yang sama di depan umum, karenanya semuanya memiliki kodrat yang sama. Oleh karena itu, demokrasi tanpa kesetaraan gender akan berdampak pada ketidak adilan sosial.

Dalam proses politik, perkembangan ke arah kesetaraan gender dalam politik di era pascareformasi 1998. Namun, hal itu hanyalah sebagian kecil solusi dalam persoalan kesetaraan gender.Masih ada banyak hal yang perlu dilakukan dalam mewujudkan kesetaraan gender, baik di bidang sosial, politik, ekonomi, pendidikan, budaya, dan lain-lain.

\section{METODE PENELITIAN}

Penelitian ini menggunakan metode penelitian kualitatif dengan pendekatan naturalistik.Penelitian kualitatif adalah metode penelitian yang digunakan untuk meneliti pada kondisi objek alamiah. Objek alamiah menurut Sugiyono (2013: 15) adalah objek yang berkembang apa adanya, tidak dimanipulasi oleh peneliti dan kehadiran peneliti tidak begitu mempengaruhi dinamika pada obyek tersebut.

\section{PEMBAHASAN}

\section{A. Pendidikan Demokrasi}

\section{Demokrasi Dalam Pandangan Pendidikan}

Demokrasi merupakan faham dan sistem politik yang didasarkan pada doktrin "power of the people", yakni kekuasaan dari rakyat, oleh rakyat, dan untuk rakyat.Bahwa rakyat adalah pemegang kedaulatan tertinggi dalam sistem pemerintahan.Demokrasi baik sebagai doktrin atau faham maupun sebagai sistem politik dipandang sebagai alternatif yang lebih baik dari pada sistem politik lainnya yang terdapat dihampir setiap bangsa dan negara.Demikian kuatnya paham demokrasi, sampaisampai konsepnya telah menjadi keyakinan politik (political belief) kebanyakan bangsa, yang pada gilirannya kemudian berkembang menjadi isme, bahkan berkembang menjadi mitos yang dipandang dapat membawa berkah bagi kehidupan bangsa-bangsa beradab.

Sedangkan pengertian demokrasi dapat dilihat dari tinjauan bahasa (etimologis) dan istilah (terminologis). Secara etimologis "demokrasi" terdiri dari dua kata yang berasal dari bahasa Yunani yaitu "demos" yang berarti rakyat atau penduduk suatu tempat dan "cratein" atau "cratos" yang berarti kekuasaan atau kedaulatan. Jadi secara bahasa demos-cratein atau demos-cratos (demokrasi) adalah keadaan negara dimana dalam sistem pemerintahannya kedaulatan berada ditangan rakyat, kekuasaan tertinggi berada dalam keputusan bersama rakyat, rakyat berkuasa, pemerintahan rakyat dan kekuasaan oleh rakyat. 
Bagaimana konsep demokrasi dalam perspektif pendidikan? Demokrasi pada dasarnya mengakui setiap warga negara sebagai pribadi yang unik, berbeda satu sama lain dengan kelebihan dan kekurangan masing-masing. Demokrasi memberikan kesempatan yang luas bagi pelaksanaan dan pengembangan potensi masing-masing individu tersebut, baik secara fisik maupun mental spiritual. Demokrasi juga mengakui bahwa setiap individu mempunyai hak dan kewajiban yang sama. Karena itu, pendidikan yang demokratis adalah pendidikan yang menempatkan peserta didik sebagai individu yng unik berbeda satu sama lain dan mempunyai potensi yang perlu diwujudkan dan dikembangkan semaksimal mungkin. Untuk itu pendidikan yang demokratis harus memberikan treatmen berbeda kepada sasaran didik yang berbeda sesuai dengan karakteristik masing-masing. Pendidikan yang demokratis juga menuntut partisipasi aktif peserta didik bersama guru dalam merencanakan, mengembangkan dan melaksanakan proses belajar-mengajar. Partisipasi orang tua dan masyarakat juga amat penting dalam merancang, mengembangkan dan melaksanakan proses pendidikan tersebut.

Demokrasi dalam lingkup pendidikan adalah pengakuan terhadap individu peserta didik, sesuai dengan harkat dan martabat peserta didik itu sendiri, karena demokrasi adalah alami dan manusiawi. Ini berarti bahwa penelitian pihak-pihak yang terlibat dalam proses pendidikan harus mengakui dan menghargai kemampuan dan karakteristik individu peserta didik. Tidak ada unsur paksaan atau mencetak siswa yang tidak sesuai dengan harkatnya.

Dengan demikian, demokrasi berarti perilaku saling menghargai, saling menghormati, toleransi terhadap pihak lain termasuk pengendalian diri dan tidak egois. Dalam proses pendidikan, semua pihak yang terkait menyadari akan alam atau atmosfir yang bernuansa saling menghargai tersebut, yaitu antara guru dengan guru, antara guru dengan siswa dan antara guru dengan pihakpihak anggota masyarakat termasuk orang tua dan lain-lain. Ini berarti bahwa dalam semangat demokrasi seorang harus tunduk kepada keputusan bersama atau kesepakatan bersama. Tidak terjadi keharusan penerimaan tanpa unsur paksaan, tetapi kesepakatan bersama yang akan menjadi sikap mereka semua. Dengan kata lain, seseorang menerima keputusan bersama dengan rasa ikhlas karena menomerduakan kepentingan pribadi dan tunduk kepada tuntutan kesejahteraan umum.

Demokrasi dalam pendidikan dan pembelajaran menggunakan pengertian equal opportunity for all artinya, anak didik mendapat peluang yang sama dalam menerima kesempatan dan perlakuan pendidikan. Guru memberikan kesempatan yang sama kepada setiap individu untuk mengikuti setiap kegiatan pendidikan.

\section{Ruang Demokrasi Pada Lembaga Pendidikan}

Dalam kaitannya tentang demokrasi dan pendidikan.John Dewey memandang pendidikan adalah kehidupan itu sendiri, lebih dari sebuah persiapan untuk hidup. Sebagai "Way Of Life" tidak dapat mungkin tercapai tanpa adanya pendidikan, sedangkan proses pendidikan itu sendiri haruslah merupakan proses yang demokratis, pendidikan yang menghargai segala perbedaan orang lain, serta menjunjung tinggi nilai-nilai kebersamaan.

Salah satu anggota Tim ICCE (2005: 7), Zamroni menyatakan : "pendidikan demokrasi yang bertujuan untuk mempersiapkan warga negara masyarakat berfikir kritis dan bertindak demokratis, melalui aktivitas menanamkan kesadaran kepada generasi baru, bahwa demokrasi adalah bentuk kehidupan masyarakat yang paling menjamin hak-hak warga masyarakat".

Menurut Sunarso (2004: 3), Pendidikan demokrasi pada hakekatnya membimbing peserta didik agar semakin dewasa dalam berdemokrasi dengan cara mensosialisasikan nilai-nilai demokrasi, agar perilakunya mencerminkan kehidupan yang demokratis. Dalam pendidikan demokrasi ada dua hal yang harus ditekankan, demokrasi sebagai konsep dan demokrasi sebagai praksis.Sebagai konsep berbicara mengenai arti, makna dan sikap perilaku yang tergolong demokratis, sedang sebagai praksis sesungguhnya demokrasi sudah menjadi sistem. Sebagai suatu sistem kinerja demokrasi 
terikat suatu peraturan main tertentu, apabila dalam sistem itu ada orang yang tidak menaati aturan main yang telah sepakati bersama, maka aktivitas itu akan merusak demokrasi dan menjadi anti demokrasi.

Tugas seorang pendidik adalah mensosialisasikan dua tataran tersebut dalam konsep dan fraksisnya, sehingga peserta didik memahami dan ikut terlibat dalam kehidupan demokrasi.

Dalam mensosialisasikan nilai demokrasi perlu adanya komitment para elit politik, tokoh masyarakat, guru, stake holders pendidikan demokrasi, dan seluruh masyarakat. Sosialisasi Pendidikan demokrasi harus memperhatikan prinsip-prinsip antara lain :

“Menurut Setyo Raharjo (2002: 28), Pendidikan demokrasi adalah suatu proses, pendekatan yang digunakan secara komperhensip, pendidikan ini hendaknya dilakukan secara kondusif baik dilingkungan sekolah, rumah dan masyarakat, semua partisan dan komunitas terlibat di dalamnya. Pelatihan pendidikan demokrasi perlu diadakan bagi kepala sekolah, guru-guru, murid-murid, orang tua murid, dan komunitas pemimpin yang merupakan asensial utama. Perlu perhatian terhadap latar belakang murid yang terlibat dalam proses kehidupan demokrasi. Perhatian demokrasi harus berlangsung cukup lama, dan pembelajaran demokrasi harus diintegrasikan dalam kurikulum secara praksis di sekolah dan masyarakat."

Pendidikan demokrasi harus direncanakan secara matang oleh stake holders baik para pakar demokrasi sebagai think-thank, kepala sekolah, guru-guru, orang tua murid, tokoh agama dan tokoh masyarakat. Pendidikan demokrasi ini harus memperhatikan nilai-nilai secara holistic dan universal.Keberhasilan pendidikan demokrasi dengan keluaran menghasilkan peserta didik memiliki kompetensi personal dan kompetensi sosial yang demokratis dan dinamis sehingga menghasilkan warga negara yang baik (good citizen).

Menurut Jimly Assiddiqie (2006: 1), Dalam mensosialisasikan nilai-nilai demokrasi pemimpin formal dan non formal bertanggungjawab untuk mewujudkan kehidupan demokrasi baik ranah organisasi negara (state), organisasi masyarakat (civil state), ranah institusi dunia usaha (market institution). Semua pejabat negara, pejabat pemerintah mempunyai tanggung jawab menjadikan jabatannya sebagai media pembelajaran pendidikan demokrasi.

Dalam analisis Dewey, pendidikan demokratis menghendaki adanya partisipasi peserta didik dalam proses pembelajaran dengan prinsip andragogi. Konsep ini berusaha mengembangkan potensi peserta didik dengan cara diberi umpan dan kail, kemudian dibimbing mncari ikan sendiri, bukan langsung diberi ikan tanpa proses pemancingan. Dengan demikian, demokrasi pendidikan lebih menekankan pada nilai-nilai kebebasan.

Menurut Zamroni (2001: 31-32), Salah satu hakikat dari pendidikan demokrasi adalah pembelajaran peran dan partisipasi seluruh elemen sekolah untuk mengarahkan perjalanan pendidikan menuju cita-cita bersama. Bentuk pendidikan demokrasi tersebut akan tumbuh dan kokoh jika dikalangan peserta didik tumbuh kultur dan nilai-nilai demokrasi antara lain toleransi, bebas mengemukakan dan menghormati perbedaan pendapat, memahami keanekaragaman dalam bermasyarakat, terbuka dalam berkomunikasi, menjunjung nilai dan martabat kemanusiaan, percaya diri atau tidak menggantungkan diri pada orang lain, saling menghargai, mampu mengekang diri, kebersamaan, keseimbangan.

Berdasarkan uraian diatas penulis dapat menyimpukan bahwa pendidikan demokrasi merupakan upaya secara sadar dan terencana untuk mengembangkan, menanamkan, membina dan mensosialisasikan prinsip, ide dan nilai-nilai demokrasi kepada peserta didik agar peserta didik memahami dan terbiasa dalam kehidupan demokrasi.

3. Sekolah Sebagai Medang Penumbuhan Nilai-Nilai Demokrasi 
Pendidikan dewasa ini harus bisa berfungsi ikut membangun kapasitas bangsa sebagai manusia pembelajar, sehingga bisa andal dan percaya diri dalam percaturan global sekarang serta rancangan ke masa depan. Dalam konteks ini, bukan hanya kukuh dan lumintu dalam visi serta cita etis pendidikan yang humanis dan religius, melainkan juga pendidikan mempunyai daya dan tata kelola untuk memperkaya kehidupan yang demokratis.

Pengembangan nilai-nilai demokratis di dekolah juga perlu diterapkan untuk menghadapi era globalisasi yang kini diyakini akan menghadirkan banyak perubahan global seiring dengan akselerasi keluar masuknya berbagai kultur dan peradaban baru dari berbagai bangsa di dunia. Itu artinya, dunia pendidikan dalam mencetak sumberdaya manusia yang bermutu dan profesional harus menyiapkan generasi yang demokratis, sehingga memiliki resistence yang kokoh di tengah-tengah konflik peradaban.

Langkah konkret yang menarik untuk direalisasi bersama, terutama oleh insan pendidik dan pihak-pihak yang berkecimpung di dunia pendidikan, adalah menciptakan ruang hidup dan praktek pendidikan sebagai sebuah kehidupan yang nyata.

Membangun pribadi yang demokratis merupakan salah satu fungsi pendidikan nasional seperti yang tercantum dalam pasal 3 UU Nomor 20/2003 tentang Sisdiknas. Di tengah-tengah gencarnya tuntutan dan suara untuk membangun Indonesia baru yang lebih demokratis di bawah pemerintahan yang bersih, berwibawa dan reformatif justru banyak politisi yang berkarakter oportunis, arogan dan mau menang sendiri, yang sangat bertentangan dengan prinsip-prinsip demokrasi yang mengembangkan nilai kebebasan, kesamaan, persaudaraan, kejujuran, dan keadilan. Padahal harus diakui, mereka memiliki kualifikasi pendidikan formal yang tinggi.Fenomena ini tentu sangat menarik untuk disimak, sebab ada kecenderungan asumsi, tinggi-rendahnya tingkat pendidikan kurang memiliki pengaruh yang signifikan terhadap tumbuhnya iklim demokrasi yang sehat.

Diperlukan upaya agar dunia pendidikan mampu menaburkan benih-benih demokrasi kepada peserta didik dan melahirkan demokrat-demokrat yang ulung, cerdas, dan andal. Beratnya beban kurikulum yang harus dituntaskan telah membuat proses belajar mengajar menjadi kehilangan ruang berdiskusi, berdialog dan berdebat, guru menjadi satu-satunya sumber belajar. Akibatnya setelah lulus mereka menjadi asing di tengah-tengah rakyat. Tidak mungkin out-put dari dunia pendidikan mampu menginternalisasi dan mengapresiasi nilai-nilai demokrasi kalau otak dan emosi mereka dijauhkan dari ruang berdialog. Mustahil mereka bisa menghargai pendapat sebagai salah satu esensi demokrasi kalau iklim belajarnya berlangsung monoton.Sehingga dunia pendidikan perlu diberi ruang yang cukup untuk membangun budaya demokrasi bagi peserta didik, sehingga kelak mereka sanggup menjadi demokrat sejati yang rendah hati, berjiwa besar, toleran, memiliki landasan etik moral dan spiritual. Apalagi di era millennium ketiga yang kini diyakini akan menghadirkan banyak perubahan global seiring dengan akselerasi keluar masuknya berbagai kultur dan peradaban baru dari berbagai bangsa di dunia, ranah demokrasi tentu akan menjadi penentu citra, kredibilitas, dan akseptibilitas bangsa kita sebagai salah satu komunitas masyarakat dunia. Itu artinya, dunia pendidikan dalam mencetak sumberdaya manusia yang bermutu dan profesional harus menyiapkan generasi yang demokratis, sehingga memiliki resistence yang kokoh di tengah-tengah konflik peradaban.

Selain pengembangan nilai-nilai demokrasi dalam pembentukan mental peserta didik sesuai nilai-nilai demokrasi, demokrasi di sekolah juga mencakup proses pembelajaran untuk meningkatkan kualitas hasil belajar. Hal ini diantaranya adalah untuk menyikapi persoalan yang tentunya tekait dengan nilai-nilai demokrasi dalam hal ilmu pengetahuan, mengenai industri saat ini yang sering menimbulkan pencemaran lingkungan.

Banyak pihak industri yang selalu berhadapan dengan kelompok-kelompok humanis yang anti pencemaran dan pengrusakan lingkungan. sehingga pendidikan harus merancang perubahanperubahan ke depan yang tetap ditandai dengan kemajuan sains dan teknologi, dengan peningkatan 
solidaritas internasional, dan keseimbangan komitmen antara produktivitas, kemajuan sains dan teknologi, yang pada gilirannya dapat mengembangkan sektor perekonomian, namun tetap memperhatikan pemeliharaan lingkungan, dan misi kemanusiaan, sehingga mampu menetralisir ketegangan-ketegangan sosial, dan mampu menjaga kelestarian alam yang tidak semata menjadi kebutuhan seluruh umat manusia dengan keseimbangan ekosistemnya, tapi juga akan diwariskan pada generasi mendatang.

\section{KESIMPULAN}

Berdasarkan hasil penelitian dan pembahasan dapat disimpulkan bahwa Implementasi Pendidikan Demokrasi Pada Mata Pelajaran IPS di SMA Negeri 6 Takalar, nilai-nilai demokrasi yang ditanamkan yaitu : Toleransi, kerjasama, kebebasan berpendapat, kebebasan berpartisipasi, kebebasan berkelompok, menghormati orang lain, kepercayaan diri dan kesadaran akan perbedaan. Implementasi nilai-nilai demokrasi dalam pembelajaran IPS di SMA Negeri 6 Takalar telah dilaksanakan melalui metode diskusi, ceramah, tanya jawab, Dan penugasan.

Faktor-Faktor Penghambat Pada Implementasi Pendidikan Demokrasi Dalam Proses Pembelajaran IPS di SMA Negeri 6 Takalar yaitu : Sarana dan Prasarana, sarana dan prasarana pendukung yang dimanfaatkan guru antara lain LCD, Laptop, dan beberapa buku referensi pendukung menjadi faktor penunjang keberhasilan proses pembelajaran.

Faktor-Faktor Pendukung Pada Implementasi Pendidikan Demokrasi Dalam Proses Pembelajaran IPS di SMA Negeri 6 Takalar yaitu : Perbedaan individual, perbedaan kemampuan antar siswa menjadi sesuatu yang tidak terhindarkan, karena setiap siswa memiliki kemampuan yang berbeda.

\section{DAFTAR PUSTAKA}

Amas Mahmud. 2011. Narasi Demokrasi. Yogyakarta: Mata Padi Persindo.

Berti Damayanti. 2016. Implementasi Pendidikan Demokrasi Dalam Mata Pelajaran IPS Di

SMP Diponegoro Majenang Cilacap.

Lincoln,A.2003.Pengertian Demokrasi. Di akses di

(http://phicumbritz.blogspot.com/2010/06/pengertian-demokrasi-menurutpara-ahli.html)

Miriam Budiarjo. 1980. Masalah Kenegaraan. Jakarta: Gramedia.

Nungki Dwi Abshita Rini. 2017. Implementasi Nilai-Nilai Demokrasi Melalui Pembelajaran Pendidikan

Kewarganegaraan.

Pupuh Faturahman. 2013. Pengembangan Pendidikan Karakter. Bandung: Refika Aditama.

Rini Yuliana. 2013. Implementasi Nilai - Nilai Demokrasi Dalam Pembelajaran Pendidikan Kewarganegaraan di SMP Negeri 3 Gringsing Batang.Skripsi.Jurusan Politik dan Kewarganegaraan.Fakultas Ilmu Sosial.Universitas Negeri Semarang.

Sugiyono. 2010. Metode Penelitian Kuantitatif, Kualitatif dan RND. Bandung: Alfabeta.

Sugiyono. 2013. Metode Penelitian Pendidikan (Pendekatan Kuantitatif, Kualitatif dan R\&D).

Bandung: Alfabeta.

Suharsimi Arikunto. 2010. Prosedur Penelitian Suatu Pendekatan Praktik. Jakarta: PT.Rineka Cipta. Sunarso, dkk.2008. Pendidikan Kewarganegaraan untuk Perguruan Tinggi. Yogyakarta: UNY Press. Supardi. 2011. Dasar-Dasar Ilmu Sosial. Yogyakarta: Ombak.

Sutopo. 2006. Metodologi Penelitian Kualitatif. Surakarta: UNS.

Tim Abdi Guru. 2006. Pendidikan Kewarganegaraan SMP kelas VII. Erlangga: Jakarta.

Tonny D. Widiastono.2004. Pendidikan Manusia Indonesia. Jakarta: PT. Kompas Media Nusantara.

Winarno. 2017. Paradigma Baru Pendidikan Kewarganegaraan. Jakarta: Bumi Aksara.

Zamroni. 2001. Pendidikan untuk Demokrasi. Yogyakarta: Bigraf Pubiishing. 